\title{
CHAIR'S MESSAGE
}

This is an exciting time for the field of Critical Criminology both in the United States and elsewhere. In the United States, for example, the Department of Justice simultaneously exonerated police officer, Darren Wilson, who had shot and killed Michael Brown, from violating Michael Brown's civil rights violations, but also released a report critical of the Ferguson Police department for numerous incidents of racial discrimination, policing for profit, and other civil rights violations against its citizens. Our membership is contributing to the analysis and participating in the activism surrounding these events.

Another development is former American Society of Criminology President Joanne Belknap's speech and subsequent recent publication in Criminology, "Activist Criminology: Criminologists' responsibility to advocate for social and legal justice." Because so much of what she writes about concerns our membership, a handful of us believe that the article warrants a reply. This has motivated University of North Carolina Professor Bruce Arrigo to edit a special issue of Critical Criminology: An International Journal, provisionally titled, "Critical Criminology as Criminological Activism: On Praxis and Pedagogy, Resistance and Revolution."

Numerous conferences and publications of interest to critical criminologists are happening in the United States and around the world. Some of these are listed in this newsletter and on the DCC Facebook page. We are particularly excited about division members participation at the Crime, Justice and Social Democracy International Conference hosted by the Crime and Justice Research Centre, QUT. Many thanks to Kerry Carrington!

We are especially proud of our accomplishments. Favian Martin has done an excellent job with the newsletter, arranging a team that has consistently assembled a respectable and exciting important information channel for our membership. Our information table at the conference was well staffed and our new banner looks amazing!

Since our twitter page was established in March 14, 2014 we have 33 followers. More impressive are our Facebook numbers. Since February 21, 2014 we have added 305 likes/followers. It has become one of the most prominent means of communicating with our membership.

In an effort to ensure that our membership has more of a say on ASC committees, in January we submitted the names of twentyone members of the DCC to serve on ASC committees. Additionally in mid-March we submitted the names of DCC members whom we believed would make excellent program and subarea chairs for the 2016 ASC annual meeting. We will also be submitting nominations for the ASC leadership elections in July. Please look for our call and consider running.

In other developments, we now have a slate of candidates for our forthcoming election. Thank you to our nominations committeeKerry Carrington, Marty Schwartz and Dawn Rothe for their hard work. Please make sure your dues are up to date so you can exercise your right to vote in the election

According to the constitution, "Only members in good standing, who have paid divisional dues, are eligible to vote at divisional meetings or elections, or to hold divisional office. (Students are not eligible to vote)."

Now is a good time to check your membership, and if it is not current, to reenroll in the DCC.

This election cycle we have contracted with Election Buddy, a third party vendor to manage the voting process. During the first week of April, members in good standing (i.e., those who have paid their dues) will receive an e-mail with instructions on how to complete your vote. Kevin Steinmetz and Donna Selman will manage the election.

In the next few months we will be diligently monitoring efforts to ensure that this years' meeting in Washington be one of the best you have experienced. Stay tuned to our website, Facebook page, twitter posts, and this newsletter.

Cordially,

Jeffrey Ian Ross, Ph.D. and Donna Selman, Ph.D.

Co-Chairs, Division on Critical Criminology

Follow us on FB and Twitter!

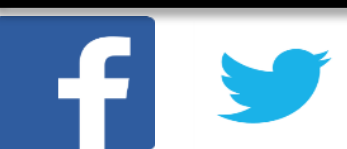




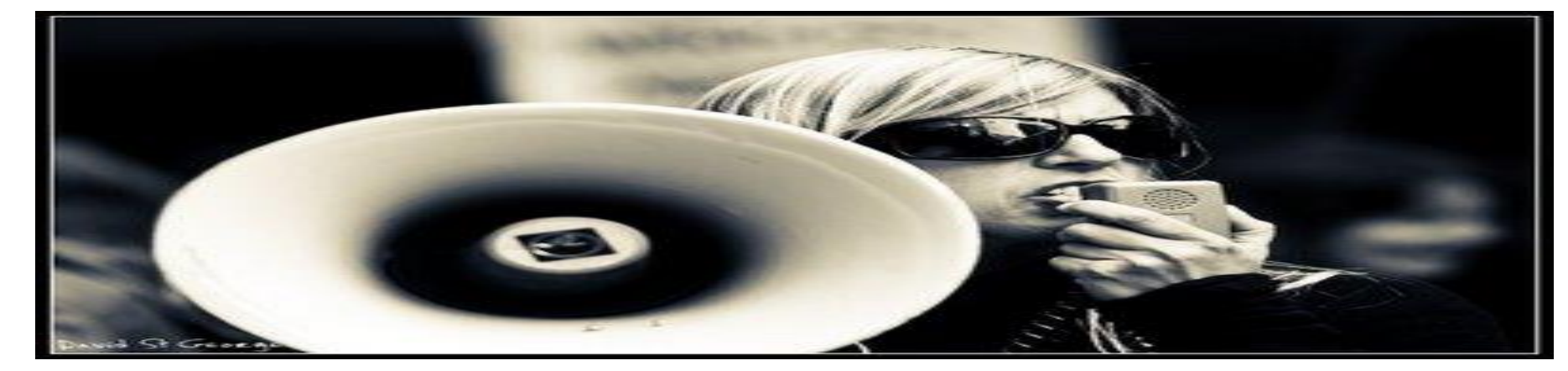

\section{CRIT CRIM NEWS}

\section{The Critical Pedagogy Collective: DCC's new Teaching Committee}

The DCC now has a Teaching Committee. At the 2014 ASC meetings the Executive Committee voted to establish such and named Carla Barrett (John Jay College) as chair. The following division members agreed to join her on this committee: Michael Coyle (Cal State, Chico), Deb Landry (University of Ottawa), Carl Root (Eastern Kentucky University), John Scott (Queensland University of Technology) and Stanislav Vysotsky (University of Wisconsin - Whitewater). This group is calling itself the Critical Pedagogy Collective and will be working on organizing and expanding the Teaching Critical Criminology Roundtables at ASC meetings, creating content on the DCC website for things pedagogical, and

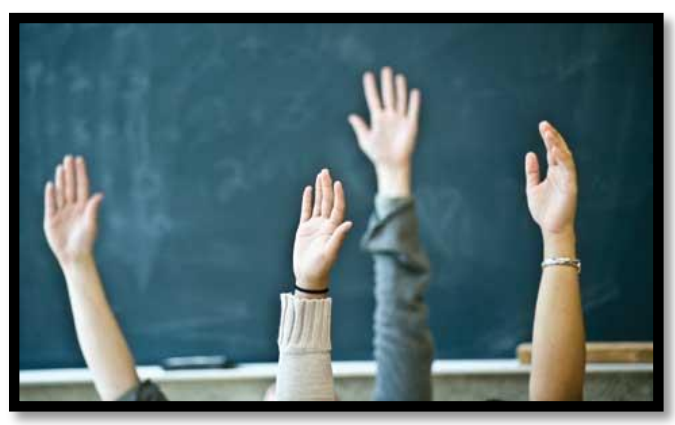
finding ways within the division to encourage scholarship and dialogue on critical teaching and learning. To that end below is the first offering in a new recurring column for the Critical Criminologist.

The Critical Teaching column will be written by rotating members of the collective and/or by others who wish to contribute. The collective envisions this column as having a broad pedagogical focus - from great teaching tips to deeper critical pedagogical musings. Any questions, ideas, suggestions regarding the Critical Pedagogy Collective can be sent to the committee at teachingcritcrim@gmail.com or to Carla at cbarrett@jjay.cuny.edu

\section{Leonidas Cheliotis Receives Award}

Dr. Leonidas Cheliotis, Assistant Professor of Criminology at the London School of Economics and Political Science, was awarded the 2015 Critical Criminal Justice Scholar Award from the Critical Criminal Justice Section of the Academy of Criminal Justice Sciences. Dr. Cheliotis was also awarded the 2014 Best Public Intellectual Special Issue Award from the Council of Editors of Learned Journals, Modern Language Association (MLA), for his guest-edited special issue of the South Atlantic Quarterly on 'Prison Realities: Views from Around the World'. The collection explores power and resistance under extreme conditions of confinement in a range of jurisdictions and from a variety of disciplinary perspectives, and includes contributions from such leading scholars as Tony Platt, Nancy Scheper-Hughes, Colin Dayan and Roy King.

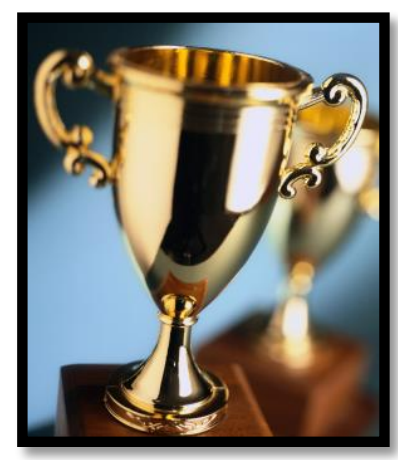




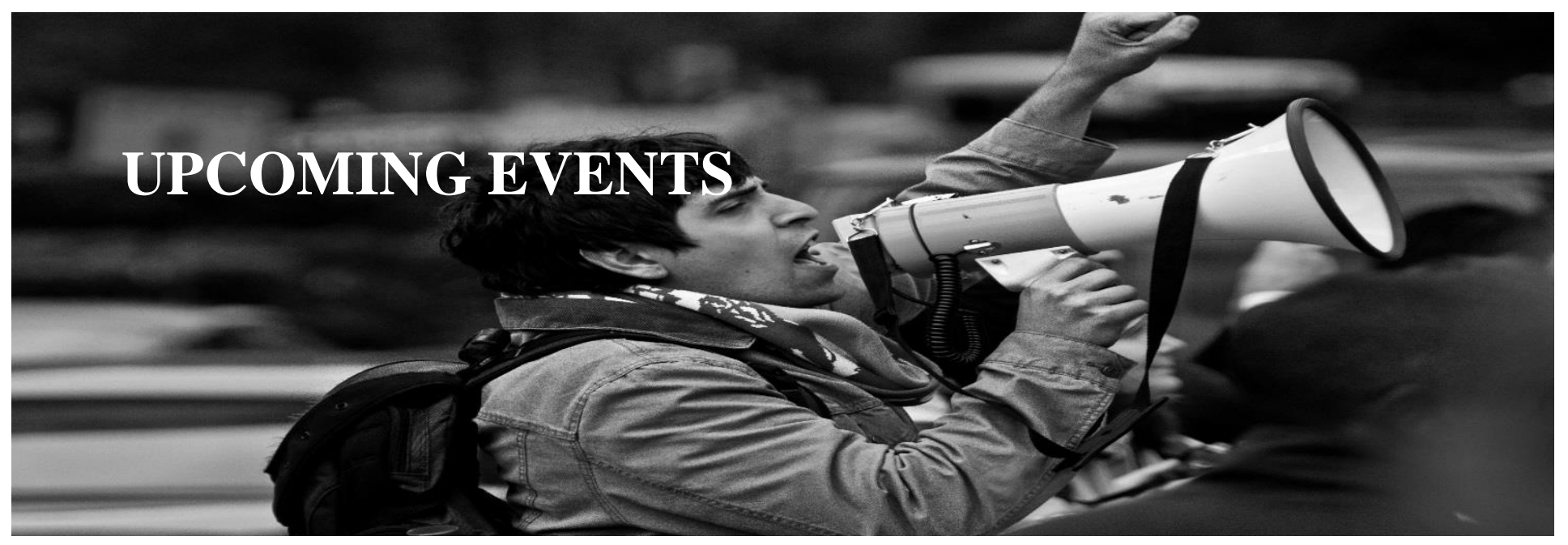

\section{Crime, Justice and Social Democracy International Conference Brisbane, Australia}

On July 8-10, 2015, the Queensland University of Technology (QUT) is hosting the Crime, Justice and Social Democracy International Conference. The aim of this conference is to reinvigorate the intellectual and policy debates about the link between social justice, social democracy and the reduction of harm, crime and victimization through the alleviation of inequalities and building of more socially just and inclusive societies (crimejusticeconference.com).

Confirmed panel speakers: Joanne Belknap (University of Colorado, Boulder, US), Avi Brisman (Eastern Kentucky University, US), Joe Donnermeyer (Ohio State University, US), Mona Danner (Old Dominion University, US), Nigel South, (University of Essex, UK), Rob White (University of Tasmania, AU), Nancy Wonders (Northern Arizona University, US), and Rob White (University of Tasmania, AU)

Abstracts are due by March 16, 2015

For inquiries, please contact: justice@qut.edu.au

\section{American Society of Criminology's Annual Conference}

The 2015 meeting will take place November 18 - 21, 2015 in Washington, DC at the Washington Hilton. The theme for the meeting is The Politics of Crime \& Justice. Thematic panels, individual paper abstracts, and author meets critics panels submissions are due by Friday, March 13, 2015 and posters and roundtable abstracts submissions are due by Friday, May 15, 2015. For additional information, please contact asc2015dc@gmail.com.

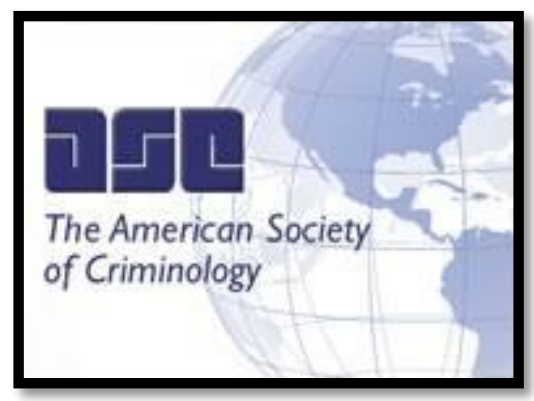




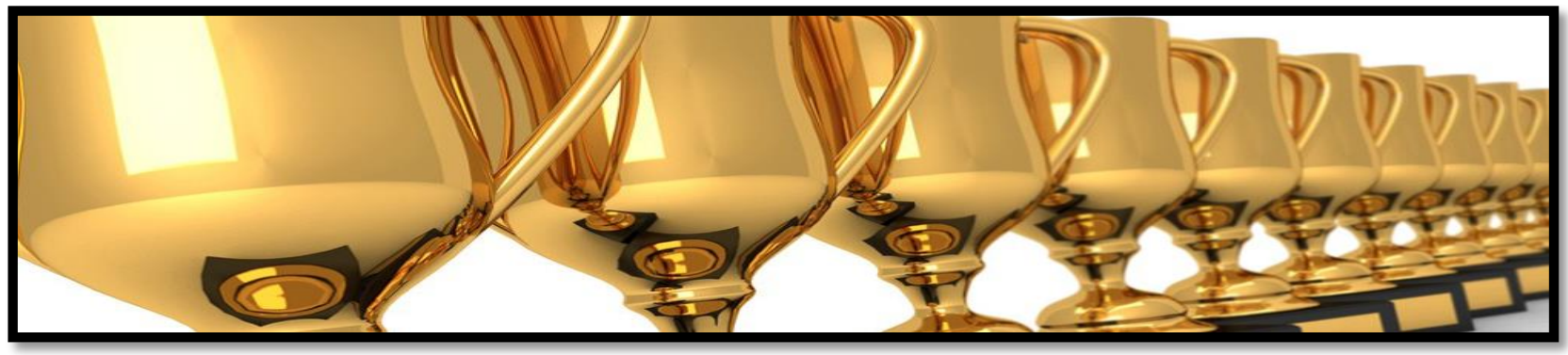

\section{AWARDS 2014 Recipients}

During the last ASC Division on Critical Criminology award ceremony in San Francisco, the Division took the time to recognize the outstanding contribution of several scholars. Here, we wanted to recognize their achievements once more.

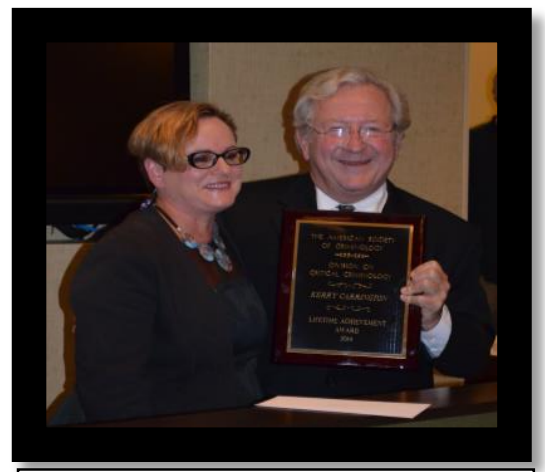

Lifetime Achievement Award: Kerry Carrington, Queensland University of Technology

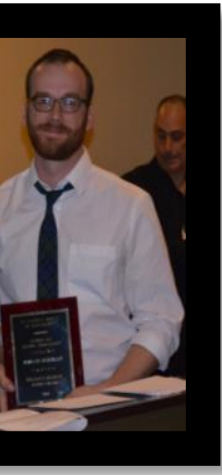

Practice Award: Matthew G. Yeager, King's University College within the University of Western Ontario, London, Ontario

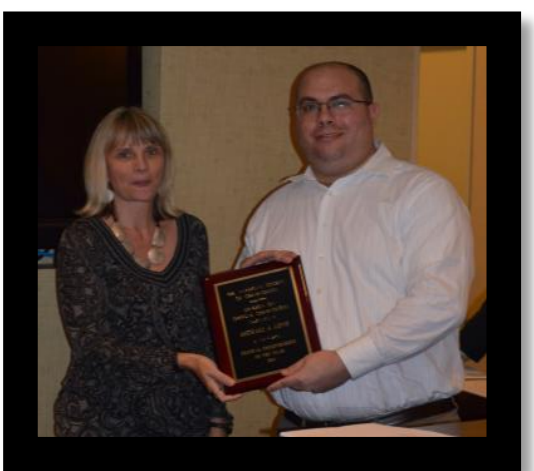

Critical Criminologist of the Year Award: Michael

A. Long, Northumbria University

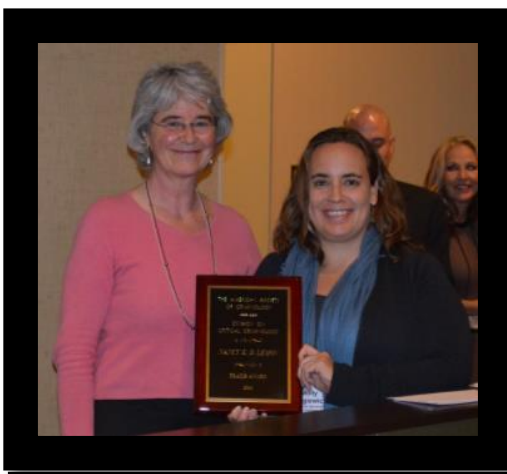

Praxis Award: Nancy K.D. Lemon, UC Berkeley (Boalt Hall School of Law)

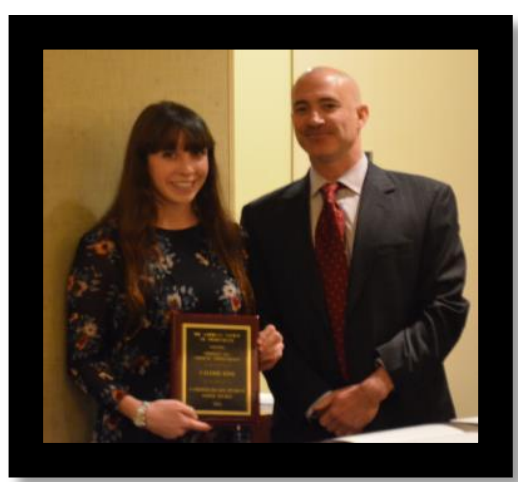

Graduate Student Paper Award: Johann A. Koehler (UC-Berkeley), "The development and fracture of a discipline: Legacies of the School of Criminology at Berkeley
Undergraduate Student Paper Award: Valerie King (University of Tennessee-Knoxville), "Constructing Victims in the International Criminal Court: A Critical Discourse Analysis" 


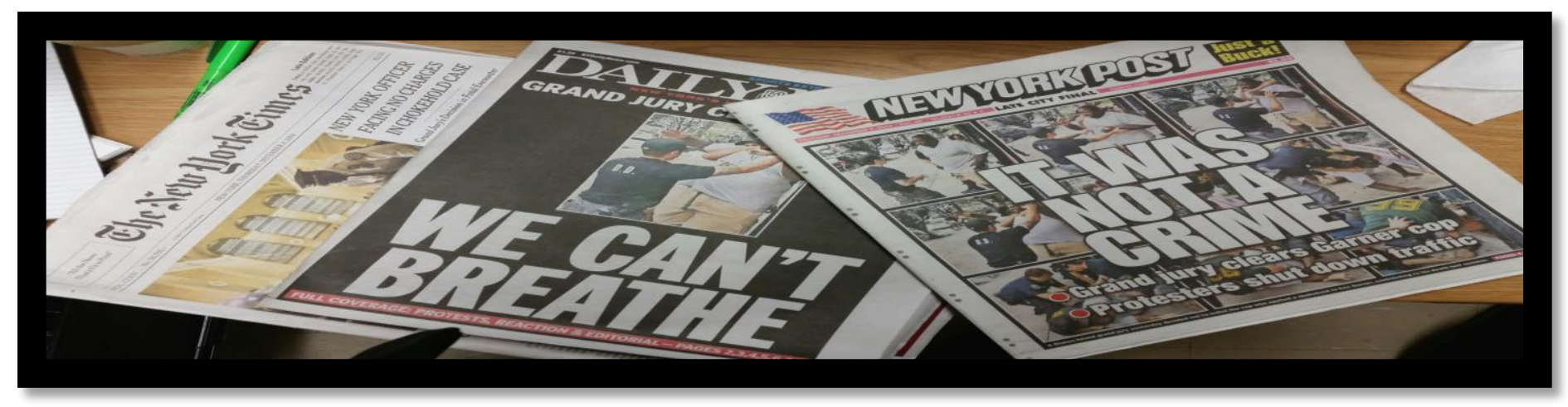

\section{Critical Teaching: Reflections on a Day of Teaching Precariously}

By Carla Barrett, John Jay College

The day after it was announced that the Staten Island Grand Jury would not indict Officer Daniel Pantaleo in the chokehold death of Eric Garner, I was scheduled to teach Juvenile Delinquency. The plan, according to my well-structured syllabus, was to discuss the important role that Alternative to Incarceration (ATI) programs can play in responding to youthful offending within a retributive system. As I rode the subway that morning to John Jay College - lesson plan complete - I was still having a hard time getting my head around the Garner decision. There was video footage after all. And this was NYC. I had hoped my city would get it right. I was surprised, yet not surprised, and that made me angry. I thought about all the issues surrounding the decision and the growing movement building across the country after Ferguson. I thought of all the families who shouldn't have had to bury Black sons.

Leaving the subway I walked past a newsstand and saw the different ways that New York's top newspapers had chosen to cover the decision:

New York Officer Facing No Charges in Chokehold Case (New York Times)

It Was Not a Crime (New York Post)

We Can't Breathe (Daily News)

Most of my students don't read old-fashioned newspapers so I decided an impromptu lesson in media representations using these papers might be in order. I bought five of each of the newspapers and headed off to campus. My plan was to truncate our discussion of ATIs and end class with students working in groups to examine the different narrative constructions in the three papers. This, I thought, would be my contribution to the discussions my students Criminology majors, Criminal Justice majors, Forensic Psychology majors, Police Studies majors - would be having in their other classes around the Brown and Garner cases.

At the beginning of class I decided to check to see what students had been talking about in other classes to make sure my newspaper exercise would offer something new.

"So are you talking about the Garner case in your other classes?" I asked. Almost all the students shook their heads "no." Since not a lot of time had passed since the news hit, I followed up with, "okay, but you've been talking about the Michael Brown case in your classes, right?" Again several students shook their heads and said, "No" or "Not really." I knew many of my colleagues had started discussions about Ferguson in their classes, but maybe not as many as I had thought. I had not started a discussion in my classes after the Brown decision. I had felt our in-class tasks on that day were too important to preempt and I assumed other professors would be leading such 
discussions. In honest hindsight I wonder if I might not have been avoiding it because I didn't quite know how to start, where to start, or how not to let my own personal feelings take over a discussion.

"So, do you want to talk about it?" I asked the class. Nearly all of my students said "yes" with an urgency that took me aback. I asked why they thought many of their professors hadn't discussed it in class more. Students offered explanations about having other things to do during class and the simple fact that the topic might be too controversial, too volatile.

"It is controversial isn't it?" I admitted. "It can feel really dangerous." I acknowledged how difficult it can be to talk about controversial topics, how difficult it often is to talk about race and racism, how many professors and students don't feel equipped to discuss such things. The majority of my students are non-white and represent a rich array of cultures and languages. I am white.

"I'll admit," I said, "it feels a little precarious for me to stand here saying these things, right now. I'm not sure how people will respond. What if I say something wrong? What if people start yelling? Some people feel that if you start talking about race, you'll sound racist. It can be really hard to do this. But I think we have to try. These things are too important. And this isn't just some college anywhere; this is the John Jay College of Criminal Justice, in New York City. I mean, we have an obligation to be talking about this, don't you think?" The students agreed. I asked them: "So what do we need to talk about?" I no longer had a lesson plan or road map. I had no idea where we would go or where we would end up. Students starting asking questions about how grand juries work and about prosecutorial discretion and power and about how the justice system could seem so unjust to so many. When I didn't have answers I said so. I brought in sociology and critical criminology themes when I thought they could be useful. I asked them to share their opinions and their experiences. One Latina student who planned to join the NYPD upon graduation spoke of her frustrations with people who sought to demonize all cops, to demonize the profession to which she was dedicated. Another student discussed her experiences being out in the street protests that had taken place the night before.

We discussed good cops and bad cops and racist cops and the complex role of cops of color and larger issues of policing within the structural context of a racist society in the age of criminalization and militarization. We discussed protesters' rights and the role of social movements in forging change. We discussed the historical roots of the fear of the Black Male. Our discussions went this way and that. Some ideas were better developed and others got totally lost. It was random and unstructured. People voiced opinions and frustrations and fears and they didn't always agree with one another, yet they remained civil with one another.

In the last few minutes I had students get into small groups to examine the newspapers I had purchased. Some groups dug into the "narrative construction" exercise I had laid out while others talked about other things that were important to them in that moment. I didn't try to bring them back to task like I normally might have. In this class, on this day, it was clear that our "task" had been simply to try to create a space for dialogue - even potentially precarious dialogue - about difficult and important things that mattered to all of us in a city, in a society, confronting legacies of oppression and definitions of justice. At the end of the class several students personally 
thanked me for the discussion. They had needed it. So had I. We had all needed a place, a space to dialogue about difficult things.

My students never did learn about the important role of ATIs in responding to youthful offending last semester, but something important happened and we were all better for it.

Precarious as it may have felt in the moment, upon reflection I will always be grateful for what my students reminded me on that day: It is okay to not know where class is headed, or even what needs to be learned. It is okay to abandon the plan. It is okay, indeed necessary, for me to be painfully honest and fully human with my students. It is okay, indeed necessary, to allow precariousness - because the precarious stuff is often the most critical.

Our work as professors is vital in ways far beyond learning outcomes and course outlines. As bell hooks has written:

The classroom, with all its limitations, remains a location of possibility. In that field of possibility we have the opportunity to labor for freedom, to demand of ourselves and our comrades, an openness of mind and heart that allows us to face reality even as we collectively imagine ways to move beyond boundaries, to transgress. This is education as the practice of freedom. (Teaching to Transgress, 1994, p. 207)
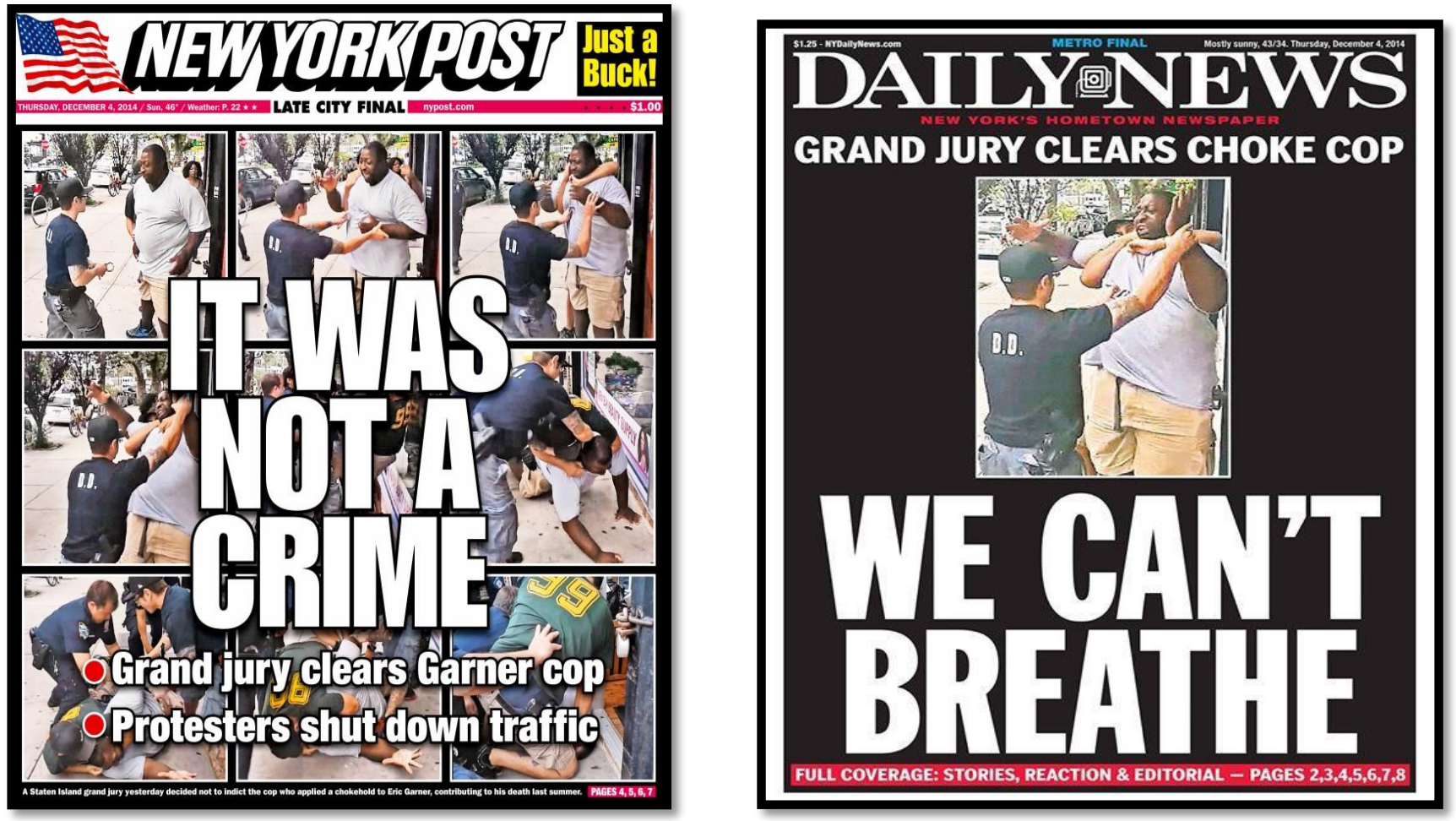


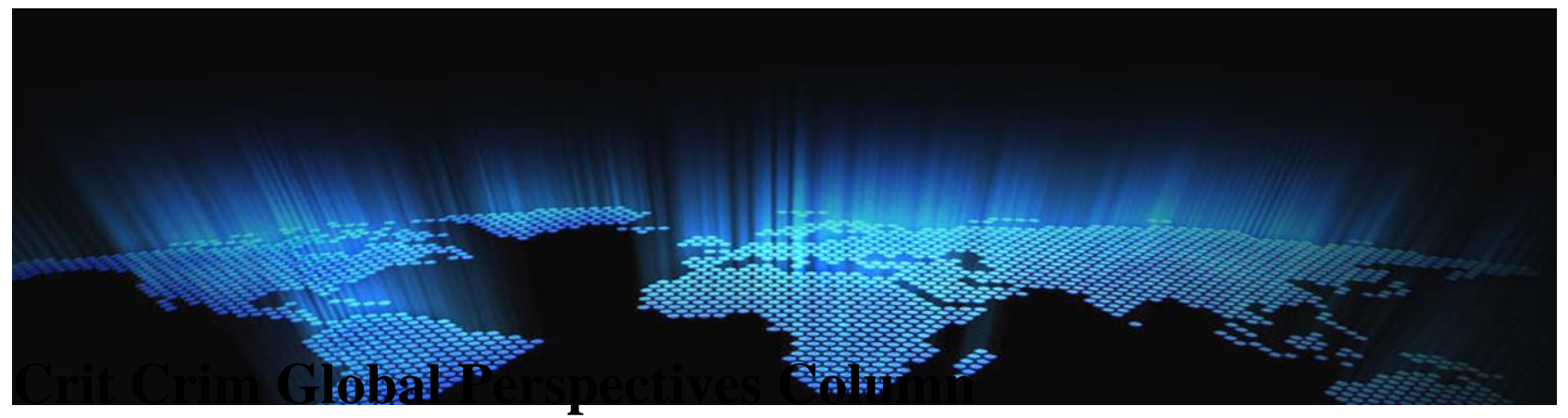

\section{The Pre-Cautionary Culture: Interpassivity and Radical Prevention in the Making of} Canada's Remand Crisis

By: Kyle Mulrooney, MA, Ph.D. Fellow Doctorate in Cultural and Global Criminology and Benedikt Lehmann, MA, Ph.D. Fellow Doctorate in Cultural and Global Criminology

There is a remand crisis in Canada. Pre-trial detention rates have nearly tripled in the past thirty years and today, of the 25,208 adults detained in Canada's provincial and territorial jails, over half are remand prisoners (54.5\%) (Porter \& Caverley, 2011; Dauvergne, 2012). These trends cannot be attributed to rising crime rates nor the absence of legislation governing the use of pre-trial detention. Both the crime rate and the violent crime rate have been on a steady decline for over the last 20 years (Boyce, Cotter \& Perreault, 2014). Further, the legal framework guiding bail in Canada, as established by the Criminal Code (S. 515) and the Canadian Charter of Rights and Freedoms (S.11(e)), mandates the presumption of release, absent conditions, unless the Crown can show just cause as to why conditional bail or the detention of the accused is justified (Meyers \& Dhillon, 2013). It would seem that the remand problem in Canada may be arising from the abstract nature of the federal legislation being translated into practice in an ad hoc manner across the provinces and territories (The Canadian Civil Liberties Association, 2014).

To understand the growth in remand populations we must look for answers in the wider criminal justice system (Meyers, 2009; Webster, Doob \& Meyers, 2009; The Centre of Research, Policy and Program Development, 2012; Ministry of the Attorney General, 2013; The Canadian Civil Liberties Association, 2014). The extant literature indicates that the increase in the use of remand may be divided into two causal factors. (1) First, despite historically low crime rates, a greater number of people are being sent to bail court and (2) second, accused are spending more time in pre-trial detention. Notably, neither an increase in bail refusals nor dwindling power resources (e.g. court capacity) can account for the expanding remand population. Rather, a number of court practices and procedures have been identified which are immediately driving the upward trends; (a) a substantial number of offences now come with a "reverse onus"; (b) the police are holding more accused for a bail hearing; (c) a substantial and rising number of administration of justice charges and cases; (d) the misuse and overuse of bail conditions; (e) an increasing number of bail court appearances to final disposition; (f) the near universal requirement that accused provide a suitable surety as a condition of release; and (g) a rising number of adjournments.

These findings lend support to a wider explanation for Canada's inflated pre-trial detention population which suggests that decisions made at various stages of the criminal justice system are being influenced by institutionalized risk aversion (Meyers, 2009; Webster et al, 2009). This demand to avert risk in the penal sphere, stemming from the growth of penal populism (Pratt, 2007), appears to be intertwined with a 'blame game', resulting in a "dangerous flight from judgment and a culture of defensiveness" (Power, 2004: 14,46). One issue with risk aversion lies 
in the process of assessing 'risk' at the bail stage. Traditional risk assessment, for example in the field of anti-terrorism, aims to calculate risk in order to arrive at a more 'rational' state of affairs where predictive statements may be made about the possibility of future harms (Beck, 1992; Zedner, 2006: 26). However, at the bail stage quantitative 'measures' of risk are not employed, time is limited and, in general, there is little information about the accused and the circumstances of the case. The absence of information renders risk assessment an altogether less plausible tool. Consequently, criminal justice practitioners seeking to avert risk and avoid blame do not operate on knowledge of risks, but rather are faced with the burden of decision-making while largely uncertain as to the nature, likelihood, scope or target of a particular threat (Zedner, 2009a: 45). According to Zizek (1998), this provokes an obscene gamble in which the individual is held accountable for decisions made "without any proper foundation in knowledge" (Zizek, 1998: 151). The liberation from risk technologies and 'rationalized' decision-making is more likely to be experienced as anxiety. In the face of anxiety, the primary response appears to be one of 'interpassivity', whereby inaction is made possible "through the sense of being active through another subject who does the job for me" (Zizek, 1998: 143). Indeed, at each stage of the bail process there is a tendency to pass along the burden of risk, responsibilizing others for decisions of release or the monitoring of the accused pre-trial (Garland, 2001; Webster et al, 2009).

However, Canada's fascination with pre-trial detention runs deeper than the efforts of individual criminal justice practitioners to avert risk and avoid blame. While no doubt part of the explanation, from our perspective the patterns highlighted in the extant literature lend support to the theoretical position of the 'security society' which maintains that the post-crime orientation of criminal justice is becoming increasingly overshadowed by the pre-crime logic of security (Zedner, 2007). In this case, Canada's bloated remand population is not a product of the extension of "formal controls of the criminal justice state" (Garland, 2001: 124), but rather the result of core criminal justice institutions themselves acting as the precautionary tools. The context of uncertainty surrounding bail warrants "governing at the limits of knowledge" and licenses a different set of techniques requiring pre-emptive action to avert potential harms (Aradau \& van Munster, 2007). Indeed, the implications of risk are not only evidenced by the "interpassivity' of practitioners, but the urgency of risk minimization necessarily lends itself to what Janus (2005; cited in Zedner, 2009: 74) has described as radical prevention. With respect to bail, practitioners seek to intervene before harm results by either incapacitating accused pre-trial or by substantially curtailing individual liberties, where there is some sort of propensity for risk. Further, "the logic of precaution spirals downward to provide a warrant for intervention in situations of uncertainty even where the anticipated harms are of a lesser gravity" (Zedner, 2009: 84). Consider that over half of those remanded in Canada have been accused of non-violent offences and that upon release from remand close to three-quarters of pre-trial detainees go on to receive a non-custodial sentence, while half are released with no further correctional involvement (Porter \& Caverley, 2011).

The forms of 'interpassivity' and radical prevention evidenced by Canadian remand practices calls attention to two key dangers of adopting a 'pre-cautionary culture'. First, it encourages actions which are incompatible with the legal intentions governing the use of remand, silences countervailing concerns and "undermines the values and principles with which we have historically sought to evaluate, regulate, and reform the criminal justice system" (Zedner, 2009: 88). Second, a pre-cautionary culture reconfigures the uses to which core criminal justice 
procedures and even institutions are put. In Canada, the conceptions of bail have shifted from a summary procedure to determine the liberty of an accused until trial, to an arena in which crime prevention aims are actively pursued (Brown, 2006; Webster et al, 2009). Most shocking perhaps is that the increased flow of pre-trial detainees into prisons is resulting in the re-organization of the Canadian penal system as a warehouse for short term risky subjects whose guilt has yet to be determined (Feeley \& Simon, 1992). Sending someone to prison is justified by the state through a combination of intended purposes weighted at varying degrees such as retribution, denunciation, general and individual deterrence, and rehabilitation. However, a penal system composed predominantly of pre-trial detainees is greatly hindered in achieving any of these purposes. It would appear that in Canada over $50 \%$ of those behind bars in provincial and territorial prisons are justified solely in the name of incapacitation. Any attempts to reform Canada's pre-trial detention system must address the 'pre-crime' logic which has grown out of the criminal justice systems pre-occupation with avoiding risk and forestalling crime.

\section{References}

Aradau, C., \& van Munster, R. (2007). 'Governing terrorism through risk: Taking precautions, (un)knowing the future'. European Journal of International Relations, 13: 89-115.

Beck, U. (1992). Risk Society: Towards a New Modernity. London: Sage.

Boyce, J., Cotter, A., \& Perreault, S. (2014). Statistics Canada, Police-reported Crime Statistics in Canada, 2012. Retrieved from http://www.statcan.gc.ca/pub/85-002-x/2014001/article/14040-eng.htm?fpv=2693

Brown, D. (2013). Looking Behind the Increase in Custodial Remand Populations. International Journal for Crime, Justice and Social Democracy, 2(2), 80-99.

Canadian Charter of Rights and Freedoms, R.S.C, (1985). Canadian Charter of Rights and Freedoms, Part I of the Constitution Act, 1982, being Schedule B to the Canada Act 1982, 1982, c11.

Criminal Code, RSC 1985, c C-46, Section 515.1. Retrieved from: http://canlii.ca/t/522v7.

Dauvergne, M. (2012). Adult Correctional Statistics in Canada, 2010-2011. Retrieved from http://www.statcan.gc.ca/ pub/85-002-x/2012001/ article/11715-eng.htm.

Feeley, M., \& Simon, J. (1992). 'The new penology: Notes on the emerging strategy of corrections and its implications'. Criminology, 30(4): 449-474.

Garland, D. (2001). The Culture of Control. Crime and Social Order in Contemporary Society. Oxford: Oxford University Press.

Janus, E. (2005). 'The preventive state, terrorists and sexual predators: Countering the threat of a new outsider jurisprudence'. Retrieved from //ssrn.com/abstract=687165.

Ministry of the Attorney General (2013). Bail Experts Table Recommendations. Justice on Target. Retrieved from

http://www.attorneygeneral.jus.gov.on.ca/english/jot/bail_experts_table_recommendations.p df.

Myers, N.M. (2009). Shifting risk: Bail and the use of sureties. Current Issues in Criminal Justice, 21(1): 127-47.

Myers, N.M., \& Dhillon, S. (2013). The Criminal Offence of Entering Any Shoppers Drug Mart in Ontario: Criminalizing Ordinary Behaviour with Youth Bail Conditions. Canadian Journal of Criminology and Criminal Justice 55(2): 187-214.

O’Malley, P. (2010). Crime and risk. London: Sage.

Porter, L., \& Calverley, D. (2011). Trends in the Use of Remand in Canada. Retrieved from http://www.statcan. gc.ca/pub/85-002-x/2011001/ article/11440-eng.htm\#a1.

Power, M. (2004). The risk management of everything. London: Demos.

Pratt, J. (2007). Penal populism. London: Routledge.

The John Howard Society of Ontario (2013). Reasonable Bail? Toronto, ON: The Centre of Research, Policy and Program Development.

The Canadian Civil Liberties Association and Education Trust (2014). Set Up to Fail: Bail and the revolving door of pre-trial detention.

Retrieved from http://ccla.org/wordpress/wp- content/uploads/2014/07/Set-up-to-fail-FINAL.pdf.

Webster, C.M., Doob, A.N., \& Myers, N.M. (2009). The parable of Ms Baker: Understanding pre- trial detention in Canada. Current Issues in Criminal Justice, 21(1): 79-102.

Zedner, L. (2006). 'Neither safe nor sound? The perils and possibilities of risk'. Canadian Journal of Criminology and Criminal Justice, 48(3): 423-34. 47

Zedner, L. (2007) 'Pre-crime and post-criminology?'. Theoretical Criminology, 11(2): 261-81.

Zedner, L. (2007b). 'Seeking security by eroding rights: The side-stepping of due process'. In B. Goold and L. Lazarus (eds.), Security and human rights (p. 257-275). Oxford: Hart Publishing.

Zedner, L. (2009a). 'Fixing the Future? The pre-emptive turn in criminal justice' in S. Bronnit, S, B. McSherry, \& A. Norrie (eds), Regulating

Deviance: The Redirection of Criminalisation and the Futures of Criminal Law. Oxford: Hart Publishing.

Zedner, L. (2009). Security. London: Routledge.

Zedner, L. (2011). Erring on the side of safety: Risk assessment, expert knowledge and the criminal court. In I. Dennis and G.R. Sullivan (eds.), Seeking Security: Pre-empting the Commission of Criminal Harms (p. 219-242). Oxford: Hart Publishing.

Zizek, S. (1998). 'Risk Society and its Discontents'. Historical Materialism, 2(1), 143-164. 


\section{Crit Crim Scholar Spotlight}

\section{By Anne Lee}

Michael A. Long Ph.D., is a leading scholar in the field of green criminology, with numerous articles on the topic. Further, he is an active member in the Division of Critical Criminology. This year Dr. Long won the Critical Criminologist of the year award. We took this opportunity to ask Dr. Long a few questions about his recent work.

\section{Q: What is a current project that you are working on? Why is it important?}

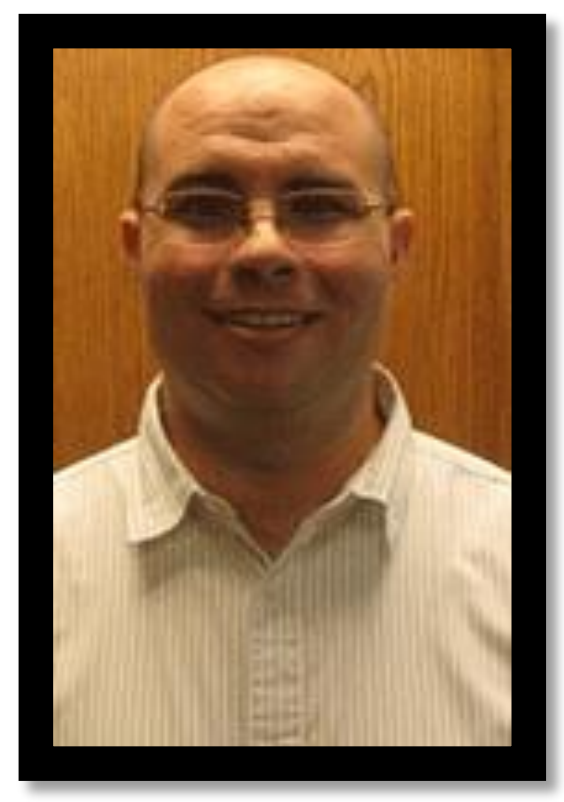

A: One of my current interests revolves around how areas affected by large-scale environmental degradation often also have high rates of traditional street crimes. In other words, do environmental crimes create social disorganization, and vice versa. For example, my colleagues and I are currently examining the impact of natural resource extraction on crime cross-nationally. One question we are currently looking at is: are countries that are heavily dependent on natural resource extraction and production for economic growth more likely to have higher homicide rates compared with countries that are not reliant on the natural resource sector? And, to what degree is crossnational natural resource extraction driven by capital originating from businesses located in other countries. In essence, we are looking at the intersection of environmental degradation, street crime and political economy. In my opinion, this area of research is important because it highlights some of the many links between the environment, crime and the economy.

\section{Q: What would you like people to know about this research?}

One of the things that I enjoy most about critical criminology is the fact that it has opened up a space in the discipline of criminology to study forms of crime that traditional criminology has historically ignored. Scholars in the areas of green crime, state and state-corporate crime, radical criminology, among others, have done tremendous work bringing attention to crimes of the powerful. However, demonstrating that some crimes of the powerful have large impacts on street crimes is also important for a more complete understanding of crime throughout the world.

\section{Q: What is next for you?}

I have recently relocated from the US to the UK. A few of my colleagues and I are in the very beginning stages of looking at green criminological issues in the UK. For example, we hope to conduct research surrounding the illegal dumping of hazardous waste in the UK, with the aim of unpacking how it occurs, identifying who are the primary offenders, and hopefully provide some research-informed solutions to the problem. 


\section{Q: Any advice to new scholars, or those new to critical criminology?}

Critical criminology is a field that enables young (and experienced) scholars to study topics that are extremely important, yet often do not receive the attention from traditional criminology that they deserve. Because of this, new scholars (particularly graduate students and assistant professors) that are interested in critical issues may wonder if they design their future research program around critical criminology that it will be undervalued in the larger discipline, and find it hard to receive good mentoring. In my experience, this could not be farther from the truth. Critical criminology is a rapidly growing sub-field with many well respected and accomplished scholars, a few of whom have had dramatic impacts on my career. I would suggest going to the ASC annual conference and other smaller meetings the focus on specific critical issues and meet people, attend critical criminology sessions, working groups, etc. and it will be quickly apparent that critical criminology is thriving and one of the most cutting edge parts of criminology. Lastly, while we often talk about "critical criminology" as one area, the truth is that it covers a wide variety of topics, from green crime to cultural criminology to feminist criminology and the list goes on. Make sure to explore all of these areas before deciding what specific areas you would like to work in. 


\section{Graduate Student Spotlight}

\section{By Ken Leon}

For this edition, we interviewed Maya Barak, who is a PhD student in the Department of Justice, Law, and Society at American University in Washington, D.C. Her research brings together the topics of law, deviance, immigration, and power, utilizing interdisciplinary approaches that span the fields of criminology, law and society, sociology, and anthropology.

\section{Q: What initially attracted you to critical criminology, and the field of criminology in general?}

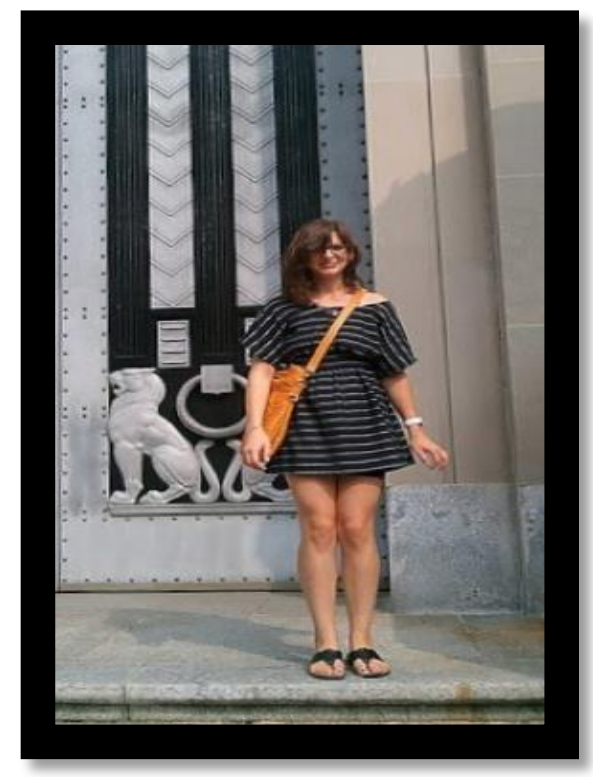

A: Critical criminology, and critical inquiry more broadly, have always been a part of my life. Although I did not realize it until relatively recently, my parents--both academics--inevitably managed to turn most dinner table conversations into exercises in critical thinking with an emphasis on social justice and inequality. During my undergraduate study at the University of Michigan, I quickly gravitated towards issues of class, race, and gender in North America, eventually leading to an interest in the criminalization of immigrants. Hence critical criminology felt like a natural fit when it became time for me to "plant my academic roots" both due to my upbringing and my deep desire to challenge traditional understandings of crime and crime control within the context of immigration.

Q: What are your current research projects? I am currently working on three research projects. A: First and foremost, I am in the midst of my dissertation, which examines the relationship between legal consciousness and procedural justice vis a vis immigration removal (deportation) hearings. While demanding, this project is incredibly enjoyable, consisting of qualitative interviews with Central American immigrants, their family members, and immigration attorneys, as well as observations of removal proceedings in three US immigration courts. In addition to the dissertation, I am coauthoring a book on the lives of capital defense attorneys with Dr. Jon Gould, a professor in the Department of Justice, Law and Criminology at American University, for which we conducted over 65 interviews with attorneys from across the country. Finally, I am also revising an article I've written on the portrayal of execution in popular film. This project involves Critical Discourse Analysis of five Oscarwinning and nominated death penalty films from the twentieth century with special attention to three linguistic tendencies--deixis, metaphor, and temporality.

\section{Q: What are your goals upon graduating from your program?}

My goal upon graduating with my $\mathrm{PhD}$ has always been to teach in higher-ed. I've been very fortunate in having had the opportunity to teach several of my own courss over the last few years, and this has only reaffirmed my desire to remain in academia. In a perfect world, I would love to one day develop and supervise a community learning program that takes undergraduate students out of the classroom through partnerships with various social justice organizations to work on participatory research projects. 


\section{Q: Who has influenced your academic career?}

A: Although it feels somewhat cliché, I have to say that I have been greatly influenced by the writings of Marx and Engels, who I consider to be two of the founding fathers of critical criminology. I have also been influenced by Howard Becker, Jon Braithwaite, William Chambliss, Michel Foucault, Erving Goffman, George Herbert Mead, and Tom Tyler for various reasons. Of course I've also been influenced by some of my past professors, like Paul Leighton, and both my parents, Gregg Barak and Charlotte Pagni.

\section{Q: What are some of your favorite academic publications? Why?}

A: One of my all-time favorite publications is Chambliss' (1964) "A Sociological Analysis of the Law of Vagrancy." The first time I read this article it really blew my mind--it just made so much sense. I also find that Chambliss' argument can be applied to America's handling of "crimmigration" over the years. From the Law and Society crowd I really enjoy Marc Galanter's (1974) "Why the 'Haves' Come out Ahead: Speculations on the Limits of Legal Change," along with a lot of the subsequent "court community" literature. I find this line of research interesting because it speaks to the patterned legal constraints (structure) individuals face and their behavior within such contexts (agency). Sally Engle Merry's (1988) "Legal Pluralism" is another one of my favorites. To me, the concept of legal pluralism is like a much-needed trip down the legal rabbit-hole, totally shaking up one's preconceived notions of "the law" and all that it entails. I could probably offer quite the long list, but I'll just mention one more--Paolo Freire's Pedagogy of the Oppressed, which I find offers up a hopeful optimism to those seeking to address the injustices of the status quo; this work is at the core of my teaching philosophy.

\section{Q: Tell us three things that you really enjoy about your field of study.}

A: I enjoy criminology's relevance to the "real world." I enjoy the company of my colleagues in the field. Most of all, I enjoy criminology's interdisciplinary nature--one never runs out of topics, theories, perspectives, frameworks, or methods to explore within our field 


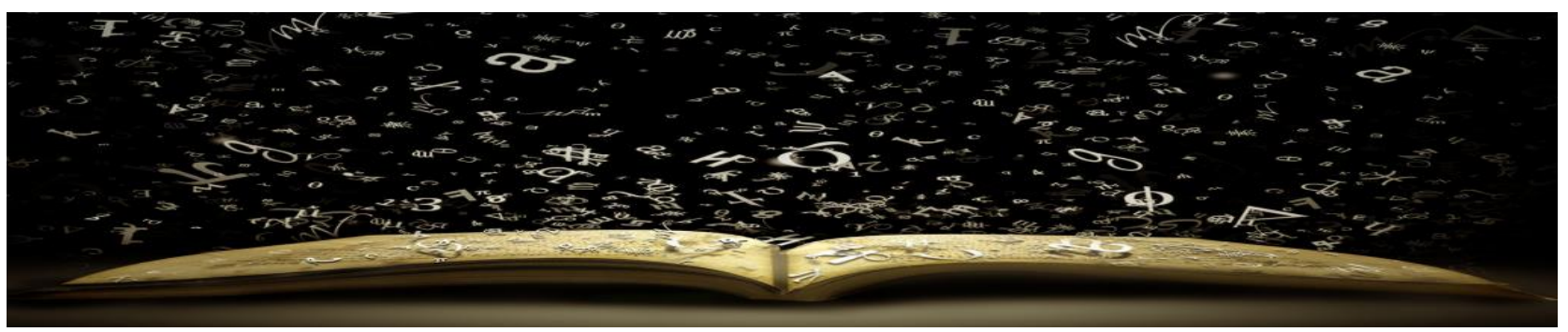

\section{Graduate Student Advice Column}

\section{Surviving the tumultuous and sometimes regrettable, yet ultimately rewarding decision to enter graduate school \\ By Kaitlyn J. Robison}

When you Google "tips for surviving graduate school", the search yields about 358,000 results. As often as graduate school is thought of as a one-size-fits-all experience (most often by those not in graduate school), we all know that it is not. Every field has its issues, and thus requires its own coping mechanisms. We're in a very particular field of study in which most of the things we read and learn about are depressing — we're constantly faced with the realities of suffering perpetuated by an inherently oppressive capitalistic society. Our particular experiences in the classroom and out in the field require that we find and create innovative survival strategies. I would like to say that I have "survived" graduate school, but I am merely surviving-I'm learning to take it one day at a time. In an attempt to build my own tool-kit, I have consulted fellow graduate students and faculty members - their trials, tribulations, and words of wisdom I share with you here, in no particular order.

1. Make your first semester about settling in. If you're like me, you have brilliant friends who are farther along in the program than you and seem to be pumping out publications in their sleep. And if you're like me, this has sent you into a wave of hysteria and feelings of uselessness - STOP freaking out, this does not need to be you yet. You're exempt from the constant push to publish for at least your first semester.

2. Speaking of the schoolwork groove...do not read everything. Unless something is particularly inspiring to you, you probably have on average 300-400 pages to read a week, papers to write, and classes to attend. Oh and eating, sleeping, and breathing. Learn the art of skimming!

3. Find your support system, and hold onto them for dear life. Faculty members, fellow graduate students, your mom, whoever it is. They are more important to this than any of us will ever realize. If you're lucky, your support system can not only motivate you to keep pushing forward, but can also ground you in the reality that there is life outside of academia.

4. Come to terms with the fact that this is going to be a long rollercoaster ride. This will not be over quickly and you will be miserable at times. Accept it, embrace it, and recognize that you need to take the bad with the good. A very wise fellow graduate student once told me that you can only really appreciate one extreme when you have also experienced the other extreme. With that said...

5. Figure out if you care enough about knowledge, social justice, and inspiring change to stay on this rollercoaster ride. If you don't, it won't be worth it in the end. The only way to get through it is to find something that pisses you off so much that you're willing to deal with minor bouts of misery. 
6. Have a life outside of school. This is hard, but probably the most necessary piece. Whether it's attending happy hour at a sketchy bar with your friends on Fridays or going to yoga on Tuesdays, DO IT. It helps with the motivation to keep facing the harsh realities that we are so often reminded of - relax and reboot.

7. With that said, remember that this is your job. If you know it takes you a full day to recover after an extended night at happy hour, or if you know that you're easily sucked into a marathon of reality TV, plan ahead for that and work around it. Don't fall behind, because it's a slippery slope.

8. Don't let the constraints of the academy stifle your creativity. It's easy to fall prey to the very things we are trying to dismantle - patriarchy, domination, oppression. Fight against it with everything you've got.

9. As one of most inspiring critical criminologists I know has said, "Practice random acts of deviance. Go native. Live, learn, and love." One of the best parts about being a critical criminologist is recognizing the value in going against everything conventional society has taught us.

10. Don't ever forget, you are smart, your work is important, and damnit, you are going to make it!

Surviving graduate school requires constant adaptation and innovation, so if anyone has any helpful advice, including mistakes to avoid, please send them my way at krobison@odu.edu 


\section{Crit Crim Meets the Arts}

By Favian Martín

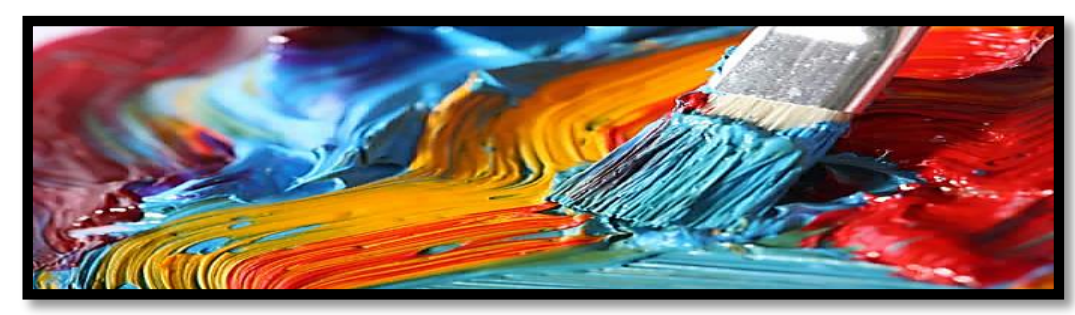

For this edition, we decided to highlight the work of the Voice Project, which advocates social change through artistic expression. According to the group's website, "in the fight against oppression and injustice, the first step is having the freedom to speak out, to raise one's voice, and it is the activist-artist who so often sounds the alarm and call others to join in action... through music and other art forms, artists around the world utilize this right to freedom of expression to clarify, engage, question, and advance the causes which help advance our species" (http://voiceproject.org/our-work/). Indeed, the group's first goal was to raise awareness through art about the atrocities occurring in Northern Uganda by the Lord's Resistance Army Insurgency. Over time, the group has extended their energies to raise awareness about human rights violations in Russia and voiced opposition to the state of Wisconsin's repeal of collective bargaining. More recently, the Voice Project has supported and promoted art associated with the Black Lives Matter movement.
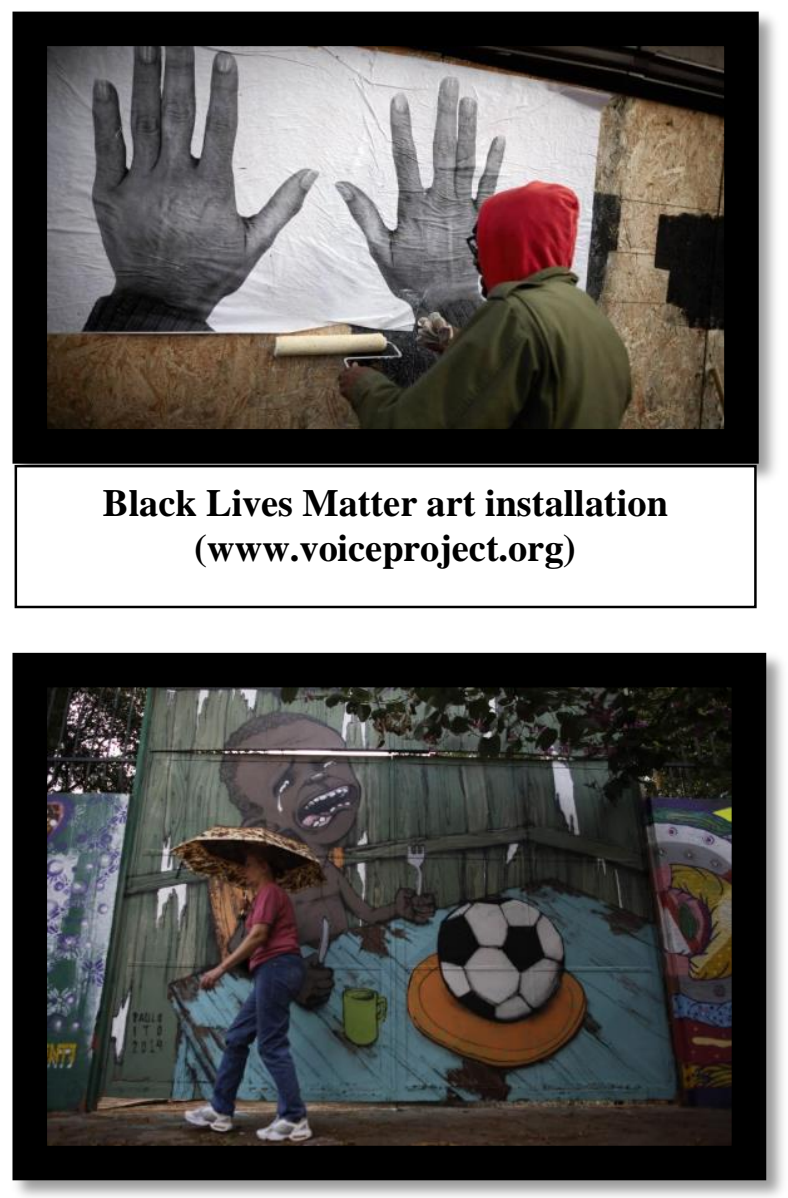
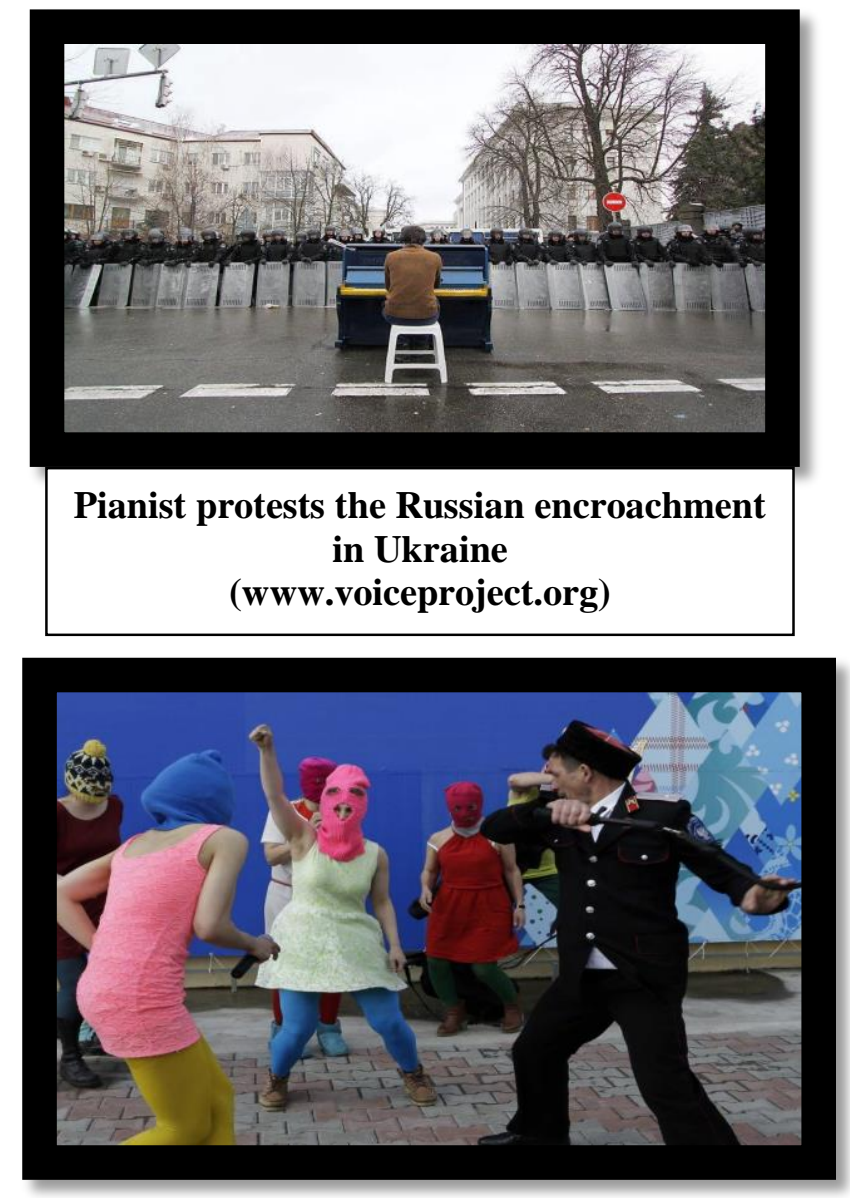


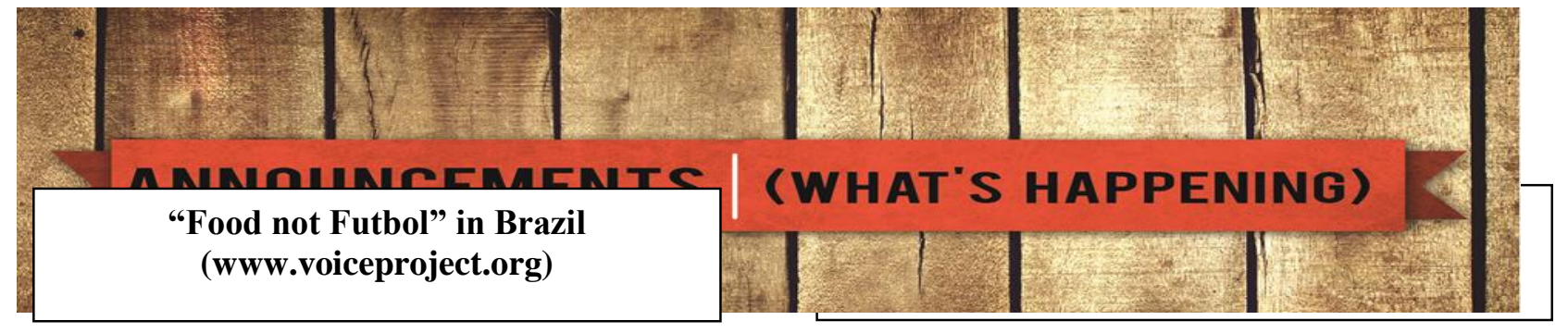

For more information about The Voice Project, visit their website: (www.voiceproject.org) 


\section{A word from our fellow Critical Criminologists....}

\section{Graduate Programs:}

Eastern Kentucky University's Master's program in Criminology and Criminal Justice is fortunate to have the funds to offer 22 Research Assistantship positions. Approximately 14 of these positions will be available for the Fall 2015 semester. Please consider our program if you or someone you know is interested in a top-notch graduate level education studying with active and engaged critical scholars in numerous important subject areas -- including, the carceral state, domestic violence, police power and over-reach, state crime, race and gender studies, cultural studies, white collar crime, rural crime and justice, human trafficking, globalization, and States' approach to drugs and terrorism. Please visit our webpage for more information about our program and faculty at http://cjmasters.eku.edu -- or write Pete Kraska (peter.kraska@eku.edu).

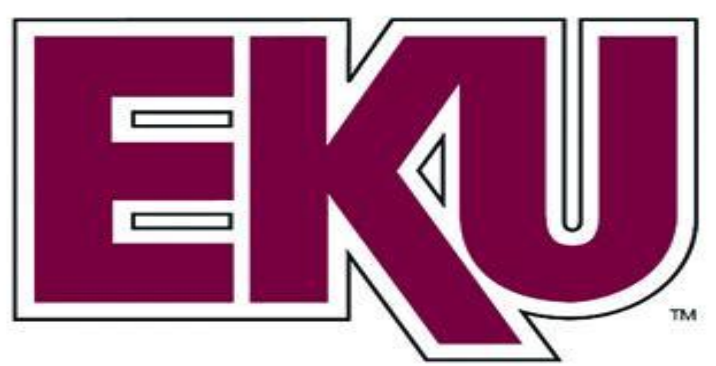

\section{Social Justice Studies}

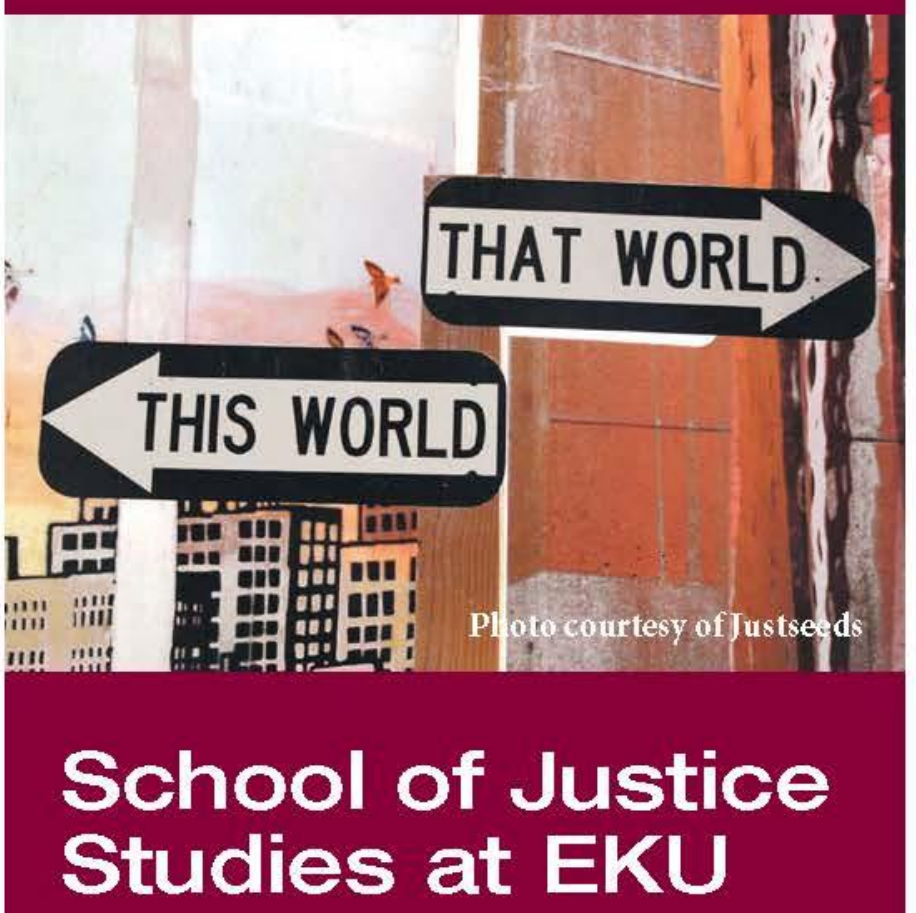

$859-622-1978$

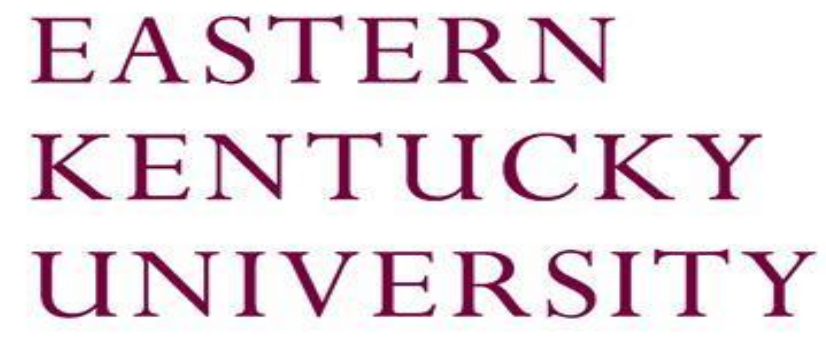

a better understanding of justice, the causes of injustice, and strategies for social change.

Program faculty seek a diverse student population that, together with faculty, will engage in a rigorous examination of pressing social problems both in the classroom and in the community in order to prepare students for various types of community engagement. Upon graduation, SJS majors will be prepared for positions in public, private, non-profit, and communitybased organizations involved in social and political activism, alternative media and education, community organizing, conflict resolution, human services, environmental advocacy, human and civil rights, public policy analy sis, and public interest law.

\section{Program Course Requirements Core (18 hours)}

- SJS 101: Understanding Social Justice and Human Struggle

- SJS 250S: Service Learning in Justice, Conflict and Social Change

- SJS 301: Theories of Social Justice

- SJS 313: Mobilizing for Social Justice

- SJS 396 Researching and Writing for Change

- SJS 450S: Learning through Civic Engagement

\section{Electives (15 hours)}


Conferences/Workshops 


\section{World Congress on Community Corrections}

July 14-16, 2015

Los Angeles, California, USA

The American Probation and Parole Association and the International Community Corrections Association are

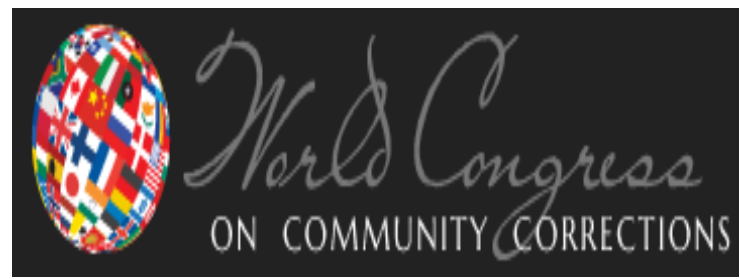
excited to invite you to join us for the Second World Congress on Community Corrections. Along with many sponsoring organizations, we look forward to offering you an outstanding selection of speakers and time to network, engage, learn, share, and build relationships across the continents.

Please join your colleagues around the world at this Second World Congress, located at Westin Bonaventure Hotel and Suites, 404 South Figueroa Street, Los Angeles, CA, 90071.

For more information, please visit:

http://www.appa-net.org/WC2015/

\section{Justice Studies Association}

May 28 - 30, 2015

Bridgewater State University (Massachusetts)

\section{Theme: Justice/Injustice, Complexities of Race}

The $17^{\text {th }}$ Annual meeting of the Justice Studies Association will be

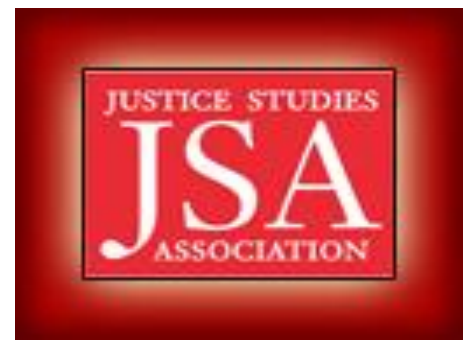
interdisciplinary as is our understanding of racial justice/injustice. Racial injustice is a global phenomenon. It is structural. It is organizational. It is personal. It is visible - invisible - overt covert. This conference will explore many aspects of racial justice/injustice on multiple levels as it intersects in all areas of society. It will raise questions, stimulate discussion, and encourage positive interactions.

The Justice Studies Association is committed to inclusiveness and welcomes presentations from teachers, activists, professionals, and community members on justice, teaching strategies, research findings, personal experiences, and artistic expressions.

For more information, please visit:

http://justicestudies.org/ 


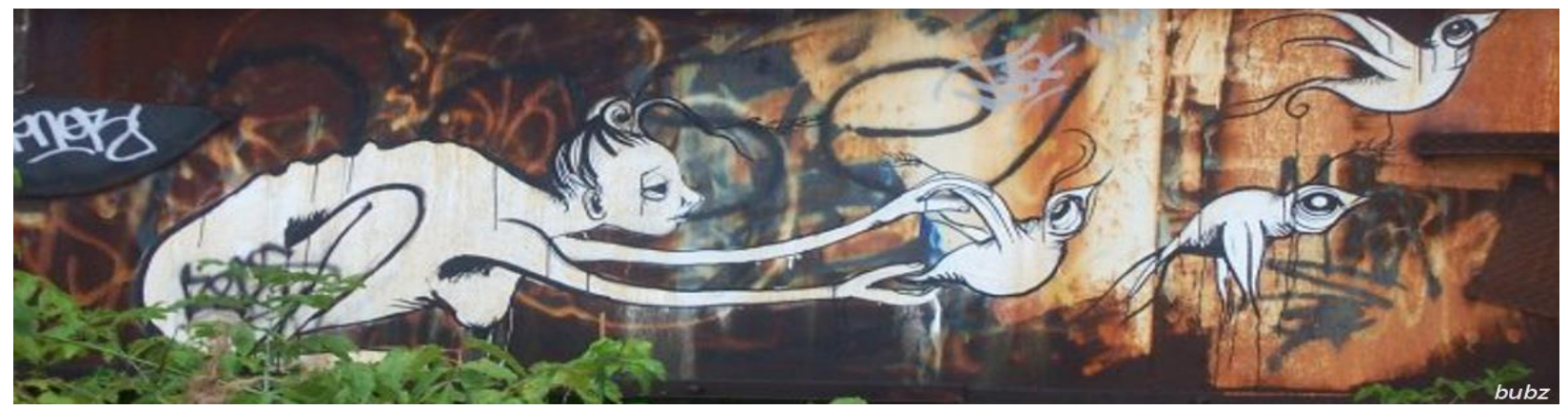

\section{UPROOTING CRIMINOLOGY SUBMISSION CALL}

Have an idea blossoming that isn't long enough to be a journal article yet (and it might not ever be)?

Consider submitting it to the Uprooting Criminology blog!

Uprooting Criminology (http://uprootingcriminology.org/) is a social justice website focusing on crime, justice, inequality, social harm and substantial structural social change. We invite original blog submissions, critical or photo essays and pedagogical (In the Classroom) submissions (http://uprootingcriminology.org/submissions/). Research, social commentary, teaching materials and cultural reviews are more than welcomed. Submissions are editor reviewed.

- $\quad$ Blog posts should be around 300 words (may include images as well as creative content such as songs or poetry). Only original submissions will be accepted, meaning content previously published elsewhere will not be considered.

- $\quad$ Critical essays are formal essays, over 1000 words in length, on any theme in line with our mission statement and consistent with our mandate (may include tables, figures, etc.). Only original submissions will be accepted.

- In the Classroom is a forum for critical academics who understand the dialectics of a classroom is as important to challenge, as is the knowledge we produce outside the classroom. We encourage teachers to share resources and ideas for fostering critical thinking in the classroom

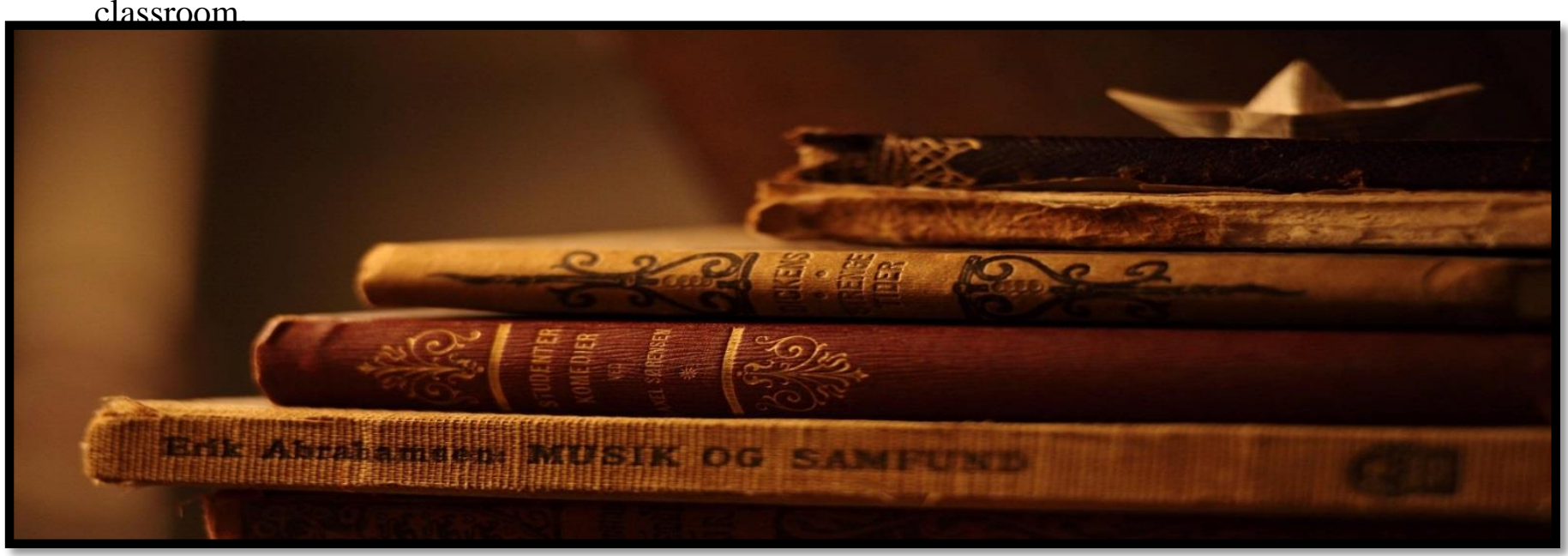




\section{Molly Dragiewicz (2015) \\ Global Human Trafficking Critical Issues and Contexts Routledge}

\section{Book Description:}

Human trafficking has moved from relative obscurity to a major area of research, policy and teaching over the past ten years. Research has sprung from criminology, public policy, women's and gender studies, sociology, anthropology, and law, but has been somewhat hindered by the failure of scholars to engage beyond their own disciplines and favoured methodologies. Recent research has begun to improve efforts to understand the causes of the problem, the experiences of victims, policy efforts, and their consequences in specific cultural and historical contexts.

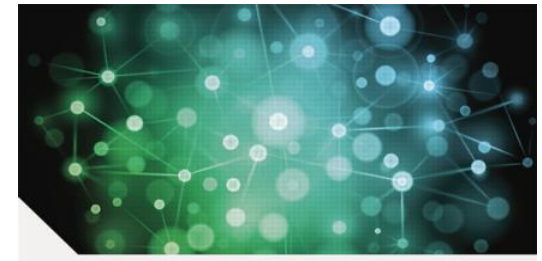

global human trafficking critical issues and contexts

edited by molly dragiewicz

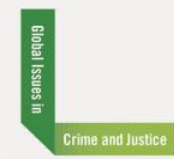

Global Human Trafficking: Critical issues and contexts foregrounds recent empirical work on human trafficking from an interdisciplinary, critical perspective. The collection includes classroom-friendly features, such as introductory chapters that provide essential background for understanding the trafficking literature, textboxes explaining key concepts, discussion questions for each chapter, and lists of additional resources, including films, websites, and additional readings for each chapter.

The authors include both eminent and emerging scholars from around the world, drawn from law, anthropology, criminology, sociology, cultural studies, and political science and the book will be useful for undergraduate and graduate courses in these areas, as well as for scholars interested in trafficking.

For more information on purchasing this book, please click on the link below:

http://www.routledge.com/books/details/9780415711104/ 


\section{Ross Coomber \\ Joseph F Donnermeyer \\ Karen McElrath \\ John Scott (2015) \\ Key Concepts in Crime and Society Sage Publications}

\section{Book Description:}

Key Concepts in Crime and Society offers an authoritative introduction to key issues in the area of crime as it connects to society. By providing critical insight into the key issues within each concept as well as highlighted cross-references to other key concepts, students will be helped to grasp a clear understanding of each of the topics covered and how they relate to broader areas of crime and criminality. The book is divided into three parts:

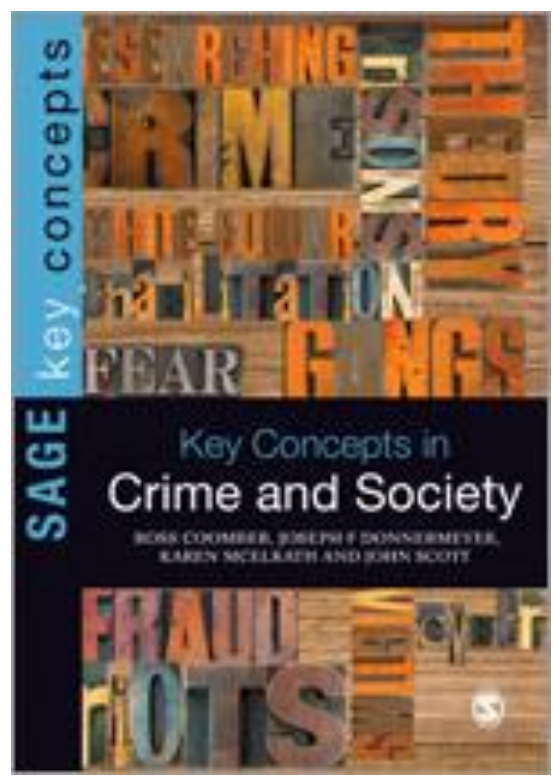

-Understanding Crime and Criminality: introduces topics such as the social construction of crime and deviance, social control, the fear of crime, poverty and exclusion, white collar crime, victims of crime, race/gender and crime.

-Types of Crime and Criminality: explores examples including human trafficking, sex work, drug crime, environmental crime, cyber crime, war crime, terrorism, and interpersonal violence.

-Responses to Crime: looks at areas such as crime and the media, policing, moral panics, deterrence, prisons and rehabilitation.

The book provides an up-to-date, critical understanding on a wide range of crime related topics covering the major concepts students are likely to encounter within the fields of sociology, criminology and across the social sciences.

For more information on purchasing this book, please click on the link below:

http://www.uk.sagepub.com/booksProdDesc.nav?prodId=Book235275\#tabview=title 


\section{Kerry Carrington (2015) Feminism and Global Justice}

\section{Book Description:}

In this book, Kerry Carrington takes a bold, critical and reflexive approach to understanding the global divisions and inequalities that shape distinctive patterns of gender and crime.

The book argues that in order for feminist criminology to enhance its conceptual and political relevance in the twentyfirst century, bold new directions in scholarship on gender, crime and global justice are required that also take into account global divisions and inequalities. Issues explored in

\section{FEMINISM AND} GLOBAL JUSTICE

Kerry Carrington

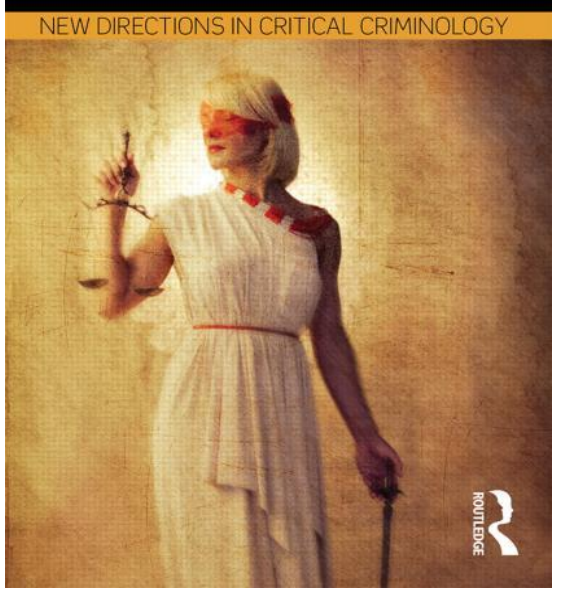
the book include the forced marriage of child brides, female genital mutilation, feminicide, honour crimes, rape and domestic violence, and the systemic denial of female rights justified by religion, custom or culture. It also explores rising rates of violence recorded for women offenders globally, and their increasing participation in terrorism, as well as troubling male-on-male violence in anomic spaces cultivated by globalising forces.

Feminism and Global Justice argues that the world needs feminism more than ever to address systemic culturally shaped and diverse forms of injustice experienced by females across the globe, many of them children. It will be essential reading for international and national human rights organisations, as well as academics and students engaged in the study of criminology, development studies, sociology, politics, and gender studies.

For more information on purchasing this book, please click on the link below:

http://www.routledge.com/books/details/9780415711128/ 


\section{Mark S. Hamm (2013) \\ The Spectacular Few: Prisoner Radicalization and the Evolving Terrorist Threat}

\section{Book Description:}

The Madrid train bombers, shoe-bomber Richard Reid, the 9/11 attacks, and now ISIS - all were led by men radicalized behind bars. Today's prisons are hotbeds for personal transformation toward terrorist beliefs and actions due to the increasingly chaotic nature of prison life caused by mass incarceration. In The Spectacular Few, Mark Hamm demonstrates how prisoners use criminal cunning, collective resistance and nihilism to incite terrorism. Drawing from a wide range of sources, The Spectacular Few imagines the texture of prisoners' lives. Hamm covers their criminal thinking styles, the social networks that influenced them, and personal "turning points" that set them on the pathway to violent extremism. Hamm argues that in order to understand terrorism today, we must come to terms with how prisoners are treated behind bars.

"Mark Hamm is, without doubt, the world's leading expert on prison radicalization. Based on decades of research, this book presents a nuanced and sophisticated picture. Beautifully written, it is the most complete, and the most empirically rigorous, account of this phenomenon to date. A must read for anyone interested in homegrown radicalization." - Peter Neumann, Director of the International Centre for the Study of Radicalization (ICSR), King's College London.

For more information on purchasing this book, please click on the link below:

http://nyupress.org/books/9780814723968/

\section{COMMUNICATION COMMITTEE MEMBERS}


Favian Alejandro Martín is an assistant Professor of Criminology and Criminal Justice at Arcadia University located in metropolitan Philadelphia in PA. He earned his

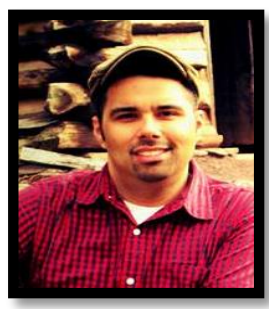
B.S. and M.A. in Criminal Justice from Pennsylvania State University and his $\mathrm{Ph} . \mathrm{D}$. in Criminology and Criminal Justice from Old Dominion University. Dr. Martín's research interests are in the areas of race and crime, immigration, restorative justice, hate crimes, and social justice.

Anne M. Lee, is a Doctoral Candidate of Criminology and Criminal Justice, at Old Dominion University in Norfolk, VA. She earned her B.S. and M.A. in

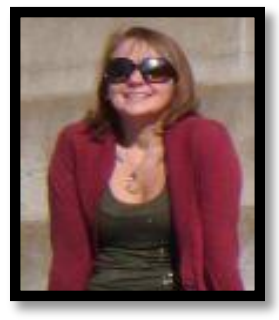
Criminal Justice and Criminology at Eastern Michigan University. She is currently working on her dissertation, The Influence of Financial Institutions and Residential Lending on Neighborhood Crime. Her research interests include corrections, prisoner reentry, communities and crime, and research methods.

Kenneth Sebastian Leon is a PhD student in the Department of Justice, Law,

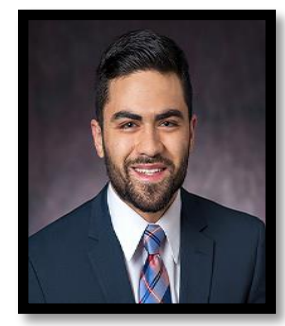
and Criminology at American University in Washington, D.C. with a dual emphasis in sociolegal studies and criminology. His primary research interests include drug policy, deviance, state power and control, classical sociological theory, and qualitative methods.

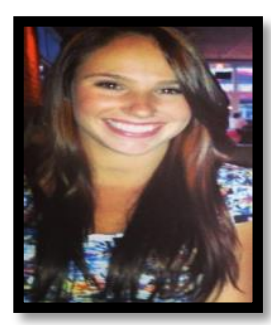

Kaitlyn Robison is a doctoral student and instructor in Criminology and Criminal Justice at Old Dominion University. Her interests lie broadly in the manifestations of inequality through punishment in terms of race, class, gender, and the intersections of each. She has specific interests in school discipline, punishment theory, and colorblind ideology.

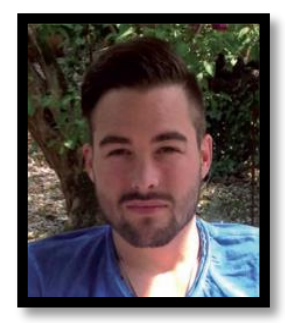

Kyle Mulrooney is currently a Ph.D. Fellow with the Doctorate in Cultural and Global Criminology, an Erasmus Mundus program of the European Union. His research is devoted to the sociological study of punishment and penal control. In particular, his Ph.D. dissertation explores the evolution of criminal justice policy in Canada with specific attention to the ways in which state processes and penal actors translate social forces into penal effects. Following this line he has also taken an interest in the doping phenomenon, examining the trend towards "zero tolerance" and the criminalization of performance and image enhancing drugs. Kyle holds a MA in the Sociology of Law from the International Institute for the Sociology of Law, Spain, and a BA (Honours) in Criminology and Justice from the University of Ontario Institute Of Technology, Canada. 